\title{
Giant Cell Tumour of the First Cuneiform: Case Study
}

\section{J.A. Enríquez-Castroa ${ }^{1 *}$, G. Estévez-Díazb ${ }^{2}$ and J.G. Segoviano-Parrac ${ }^{3}$}

${ }^{1}$ Orthopaedic Specialist, Foot and Ankle Module Coordinator of Hospital General de México Dr. Eduardo Liceaga, Mexico City,Mexico

${ }^{2}$ Attending Physician assigned to the Foot and Ankle Module of Hospital General de México Dr. Eduardo Liceaga, Mexico City, Mexico

${ }^{3}$ Third Year Orthopaedic Resident, Hospital General de México Dr. Eduardo Liceaga, Mexico City, Mexico

*Corresponding Author: J.A. Enríquez-Castro, Orthopaedic Specialist, Foot and Ankle Module Coordinator of Hospital General de México, Mexico City, Mexico. E-mail: drenriquezja@hotmail.com

\section{Received date: July 09, 2019; Accepted date: September 12, 2019; Published date: September 13, 2019}

Citation: J.A. Enríquez-Castroa , G. Estévez-Díazb and J.G. Segoviano-Parrac. Giant Cell Tumour of the First Cuneiform: Case Study, J. Cancer Research and Celllular Therapeutics,3(1). Doi: 10.31579/2640-1053/053.

Copyright:@2019 J.A. Enríquez-Castroa, This is an open-access article distributed under the terms of the Creative Commons Attribution License, which permits unrestricted use, distribution, and reproduction in any medium, provided the original author and source are credited

\section{Abstract}

Giant cell tumours (GCT) are usually benign, locally aggressive tumours. They tend to occur in long bones and rarely in small bones, with an incidence rate of 1.2 to $2.4 \%$ in the bones of the foot. The objective is to present a unique case in the literature of a GCT that only affected the first cuneiform. We present the case of a 35-year-old male patient seen at Hospital General de México (HGM) with seven months history of pain and increased volume in the medial region of the right foot, with X-ray and MRI images consistent with GCT in first cuneiform of the right foot. The excisional biopsy confirmed GCT. The definitive treatment consisted of curettage, cryotherapy with nitrogen and heterologous bone graft placement. Evolution was satisfactory, with no pain, no volume increase, normal gait and radiographic bone graft integration. Follow-up was at six years.

Keywords: giant cell tumour (GCT); first cuneiform

\section{Introduction}

GCT is an aggressive local tumour containing mononuclear stromal cells and multiple multinucleated giant cells. It is the sixth most common primary bone cancer. It is predominant in women, with a ratio of $2: 1$, and presents from 20 to 40 years of age. $60 \%$ are found in long bones, primarily the distal femur, proximal tibia, distal radius and proximal humerus, and represents $20 \%$ of all primary bone tumors in the foot and ankle. ${ }^{1--6}$

They are not very common in the small bones of the hands, feet and ankles..$^{5-7}$ Only 6\% of GCTs occur in the ankle and foot, with the distal tibia being the most common location. ${ }^{3,6}$ Their incidence in small bonesis $1.2-2.6 \% .^{2,4,7,8,9} \mathrm{Jae}$ et al. ${ }^{9}$ reported a case affecting the first and second cuneiforms and the bases from the first to the third metatarsal, ${ }^{9}$ Wendi O'Connor et al. ${ }^{10}$ reported a case affecting the third cuneiform with extension towards the second ${ }^{10}$, Roberto Biscaglia et al. ${ }^{7}$ reported 2 patients with involvement of the first cuneiform and adjacent bones and another patient with involvement of the third cuneiform and cuboid bones $^{7}$ and Hannah L. Co et al. ${ }^{8}$ reported a GCT foot incidence of $2.6 \%$ (7/269), the most commonly involved bone was the talus (4/7 or 57\%) with one case each involving the cuboid, calcaneus, and the first metatarsal. ${ }^{8}$ We report the case of a patient with a single expansionary lesion only affecting the first cuneiform of the right foot.

\section{Case report}

35-year-old male with onset in December 2012, characterized by increased volume in the medial face of the right foot, together with burning pain of 5/10 intensity on the Visual Analogue Scale (VAS), which increased to $8 / 10$ when walking and upon palpation. He underwent infiltration privately but the symptoms continued and the pain progressively increased to VAS 8/10, with further increased volume. He came to HGM on July 2013 with gait affected due to the right leg, with a hard, non-mobile tumour measuring $3 \mathrm{~cm} \times 3.5 \mathrm{~cm} \times 0.5 \mathrm{~cm}$ in the first cuneiform, painful upon palpation. X-rays showed a $2.2 \mathrm{~cm} \times 3.3 \mathrm{~cm}$ lytic lesion in the first cuneiform with round, sclerous edges and no periosteal reaction. The MRI (Figs. 1 and 2) showed a multi-lobe $3.2 \mathrm{~cm} \times 2.2$ $\mathrm{cm} \times 5.2 \mathrm{~cm}$ lesion affecting the entire first cuneiform, with integral, sclerous edges and hyperintense areas in $\mathrm{T} 2$.

An excisional biopsy was performed on July 29, 2013, showing GCT (Fig. 3). The definitive treatment consisted of curettage, cryotherapy and heterologous bone graft placement (Figs. 4 and 5). Evolution was satisfactory, with no pain or volume increase, normal gait and radiographic graft integration. Follow-up was at six years (Fig. 6 and 7). 

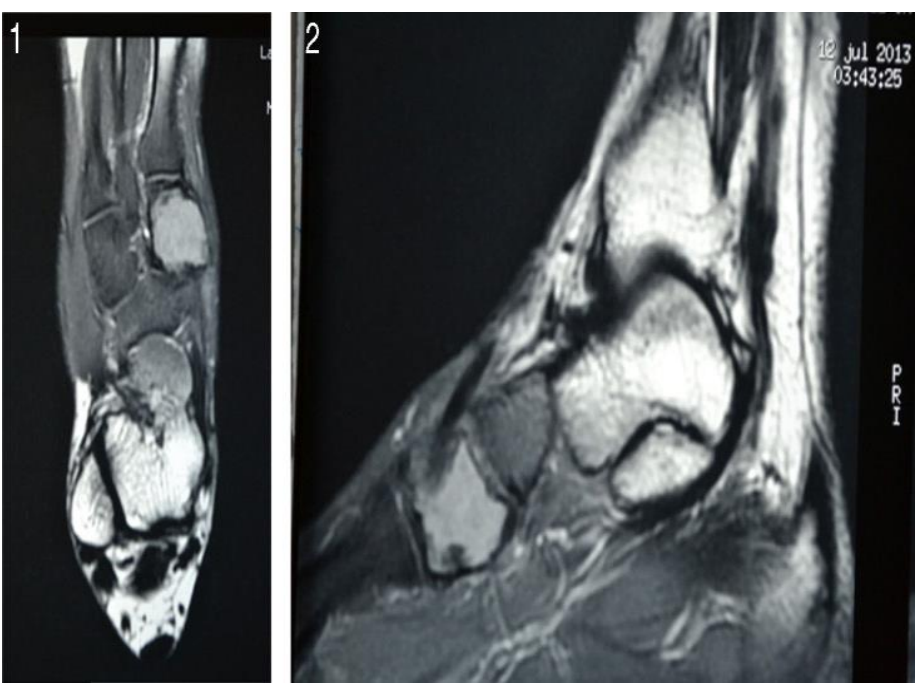

Figures 1 and 2. MRI of the foot. Multi-lobe lesion involving only the first cuneiform, with hyperintensity in $\mathrm{T} 2$.

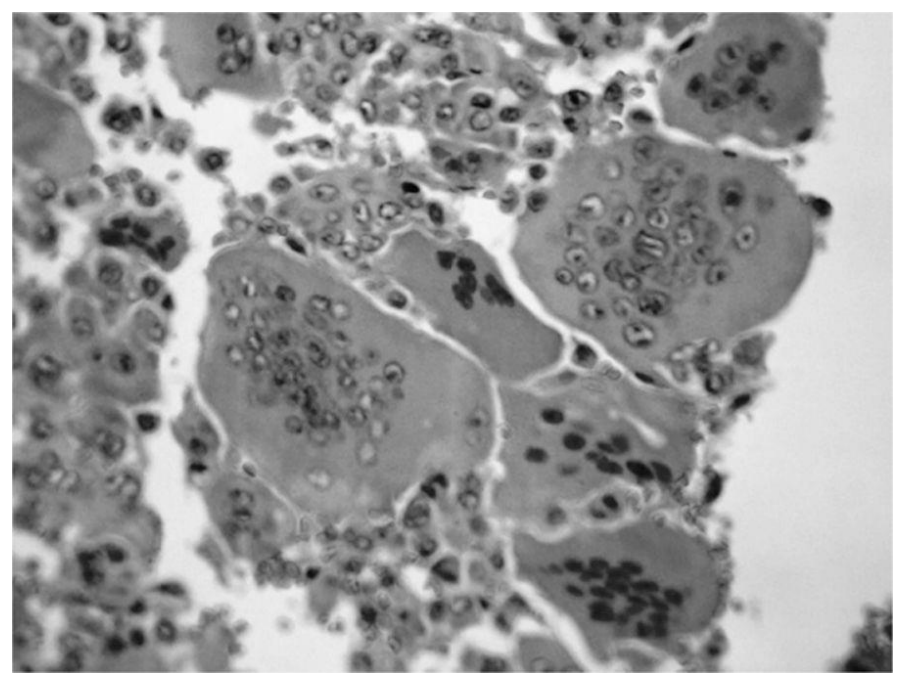

Figure 3. Microscopic image of GCT. It shows mononuclear cells and numerous giant cells distributed in a non-uniform manner.
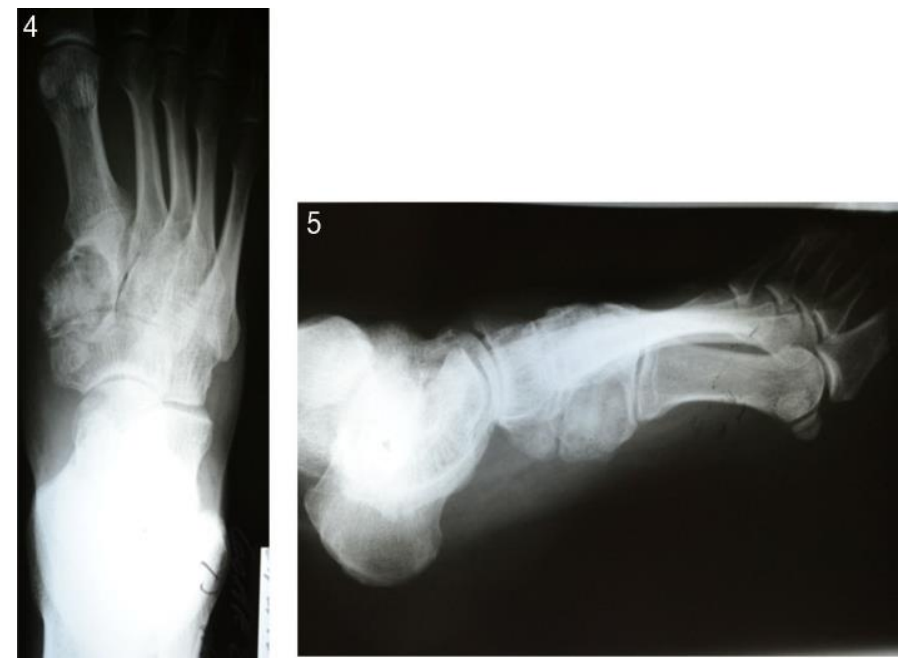

Figures 4 and 5. Post-surgical foot X-rays. They show tumour cavity with bone graft.
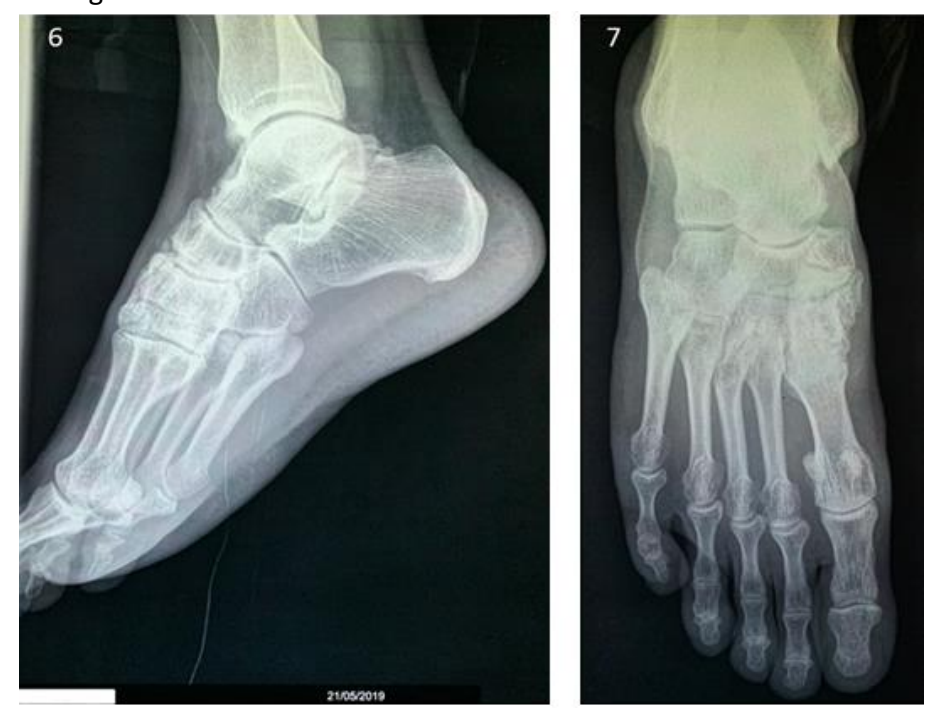

Figures 6 and 7. Control foot $\mathrm{X}$-rays at 6 years. They show integrate bone graft.

\section{Discussion}

In GCTs, pain is the predominant symptom, followed by increased volume due to tumour growth or oedema and, thirdly, fracture at the affected site, as reported by Dahlin, Osman and Biscaglia. ${ }^{2,3,7}$ According to Kwang-Son and Jae Hoon, ${ }^{5,9}$ diagnosis and treatment is delayed by more than 6 months. The patient presented burning pain and increased volume and was diagnosed after 7 months, consistent with the literature. According to Green, Dahlin, Jae Hoon and O'Connor, ${ }^{1,2,9,10}$ it presents in most patients from the age of twenty toforty years. This is consistent with the case report.

It is rarely found in the small bones of the foot, with an incidence rate of 1.2 to $2.6 \%$. $^{2,47,8,9} \mathrm{Jae}$ et al. ${ }^{9}$ reported a case where the first and second cuneiforms and the bases from the first to third metatarsal were affected; Wendi O'Connor et al. ${ }^{10}$ reported a case in which the third cuneiform, with extension towards the second, was affected; Roberto Biscaglia et al. ${ }^{7}$ reported 2 patients with involvement of the first cuneiform and adjacent bones, and another patient with involvement of the third cuneiform and cuboid bones; Hannah L. Co et al. ${ }^{8}$ reported a GCT foot incidence of $2.6 \%$ (7/269), the most commonly involved bone was the talus $(4 / 7$ or $57 \%$ ) with one case each involving the cuboid, calcaneus, and the first metatarsal. ${ }^{8}$ In the HGM orthopaedics department, the most common site for GCT affecting small bones is the ankle, followed by the heel bone. This is the first case affecting the first cuneiform, which is consistent with the literature, in that GCTs are rarely found on the small bones of the foot. ${ }^{2,4,7--10}$

The patient's X-rays showed an expansionary osteolytic lesion with defined sclerous edges and occasional stringiness, consistent with Green, Dahlin and Kwang, ${ }^{1,2,5}$ and this was confirmed by the MRI. ${ }^{9,11}$ Histologically, Green, Dahlin and Walid Osman ${ }^{1--3,11}$ refer to a double population of mononuclear stromal cells and giant cells uniformly distributed throughout the tumour, as reported in the patient's biopsy. 
There are multiple forms of treatment: curettage, abrasion debridement, cryotherapy with different elements, use of phenol or phenol combinations and graft. 1,2,5--7,9,11 The patient was treated with curettage plus cryotherapy and graft, with satisfactory evolution. Denosumab a RANK ligand inhibitor, should be incorporated in the standard multidisciplinary treatment in patients with advanced GCT that are not candidates for primary curettage. ${ }^{13}$

According to Campannaci and F. Abat, ${ }^{12,14}$ the recurrencerate is around $25.8 \%$ to $27 \%$. Malignance recurrencerate is around $7.2 \%$ to $10 \%$ consistent whit literature. ${ }^{12}$

\section{References}

1. Greenspan A. Tumores de huesos y articulaciones. Marban, Spain. p. 311---22.

2. Dahlin DC, Cupps RE, Johnson EW.(1969). Giant Cell tumor: a study of 195 cases. Cancer. ; 25:1061-70.

3. Osman W, Mohamed J, Abdelkrim SB, et al. (2014). Giant cell tumor of the lower end of tibia. Curettage and cement reconstruction. J Foot Ankle Surg. x: 1-5.

4. O'keefe RJ, O’Donnell RJ, Temple T, et al. (1995). Giant cell tumor of bine in the foot and ankle. Foot Ankle Int. 16:617.

5. Song KS, Park CH. (2014). Giant cell tumor of the talus: 19year follow- up of a patient. J Foot Ankle Surg. :1-4.
6. Rajani R, Schaefer L, Scarborough MT, et al. (2015). Giant cell tumor of the foot and ankle bones: high recurrence rates after surgical treatment. J Foot Ankle Surg. 1-5.

7. Biscaglia R, Bacchini P, Bertoni F. (2000). Giant cell tumor of the bones of thhand and foot. Cáncer Cytopathol. ;88: 20-22

8. Co H, Wang E. (2018). Giant cell tumor of the small bones of the foot. Journal of Orthopaedic Surgery.;26(3):1-5

9. Ahn J, Choy W, Kim H, Kim H. (2011). Midfoot Reconstruction for a Large, Aggressive Giant-Cell Tumor. The Journal of Bone and Joint Surgery-American Volume.;93(22):e133(1)-e133(6).

10. Willis M, O'Connor W, Quintana M, Smith S, McCartney W. (2014). The Hypermetabolic Giant: 18F-FDG avid Giant Cell Tumor identified on PET-CT. Journal of Radiology Case Reports.; 8(6).

11. Bos GD, Esther RJ, Woll TS. (2002).Foot tumors: diagnosis and treatment J Am Acad Orthop Surg. ;10:259

12. Abat F, Almenara M, Peiró A, Trullols L, Bagué S, et al. (2019). Tumor de células gigantes óseo. Noventa y siete casos con seguimiento medio de 12 años.

13. Van der Heijden L, Dijkstra P, Blay J, Gelderblom H. (2019). Giant cell tumour of bone in the denosumab era.

14. Campanacci M, Baldini N, Boriani S, Sudanese A. (1987). Giant-celltumor of bone. J Bone Joint Surg Am.; 69:106. 